\title{
FIRST RECORD OF HYDROLAGUS AFFINIS (HOLOCEPHALI: CHIMAERIFORMES: CHIMAERIDAE) FROM MADEIRA AND THE SEINE SEAMOUNT (NORTH ATLANTIC OCEAN)
}

\author{
Mafalda FREITAS ${ }^{1 *}$, Armando J. ALMEIDA ${ }^{2}$, João DELGADO ${ }^{3}$, José A. GONZÁLEZ ${ }^{4}$, \\ José I. SANTANA ${ }^{4}$, and Manuel BISCOITO ${ }^{5}$ \\ ${ }^{1}$ Estação de Biologia Marinha do Funchal, Cais do Carvão, Funchal, Madeira, Portugal \\ ${ }^{2}$ Faculdade de Ciências da Universidade de Lisboa, Dep. de Biologia Animal, Laboratório Marítimo da Guia, \\ Avenida Nossa Senhora do Cabo 939, Cascais, Portugal \\ ${ }^{3}$ Direcção de Serviços de Investigação das Pescas, Estrada da Pontinha, Funchal, Madeira, Portugal \\ ${ }^{4}$ Instituto Canario de Ciencias Marinas, P.O. Box 56, 35200 Telde, Las Palmas, Spain \\ ${ }^{5}$ Museu Municipal do Funchal (História Natural), Rua da Mouraria 31, Funchal, Madeira, Portugal
}

Freitas M., Almeida A.J., Delgado J., González J.A., Santana J.I., Biscoito M. 2011. First record of Hydrolagus affinis (Holocephali: Chimaeriformes: Chimaeridae) from Madeira and the Seine Seamount (North Atlantic Ocean). Acta Ichthyol. Piscat. 41 (3): 255-257.

\begin{abstract}
The smalleyed rabbitfish, Hydrolagus affinis (de Brito Capello, 1868) (Chimaeridae), is recorded from the archipelago of Madeira for the first time, based on seven specimens caught between 1200 and $2500 \mathrm{~m}$ depth. This record extends the previously known range of distribution of this species, and also confirms its vertical distribution down to $2500 \mathrm{~m}$. Additional material collected from the Canary Islands and the Azores was used for comparison.
\end{abstract}

Keywords: Chimaeridae, Hydrolagus affinis, Madeira, NE Atlantic

The family Chimaeridae comprises two genera, Chimaera L. (with a separate anal fin, sharply marked off from the caudal fin by a deep notch) and Hydrolagus Gill, 1862 (without a separate anal fin) (Bigelow and Schroeder 1953). Hydrolagus is represented by 22 described species (James et al. 2009, Eschmeyer 2010), four of them known from the north-east Atlantic: Hydrolagus affinis (de Brito Capello, 1868), H. lusitanicus Moura, Figuereido, Borlado-Machado, Almeida et Gordo, 2005, H. mirabilis (Collett, 1904), and H. pallidus Hardy et Stehmann, 1990.

Hydrolagus affinis was first described from a single specimen caught off Setúbal, east Portugal (Capello 1868). It is a benthopelagic species occurring on continental slopes and deep-sea plains from 300 to $2400 \mathrm{~m}$ (Stehmann and Bürkel 1984). Its distribution extends from East Greenland (61 $\left.{ }^{\circ} 50^{\prime} \mathrm{N}\right)$, Rockall Trough, Bay of Biscay and off Portugal to $22^{\circ} 52^{\prime} \mathrm{N}$ to off northwest Africa, including the Canary and the Cape Verde Islands in the East Atlantic (Stehmann and Bürkel 1984, Hardy and Stehmann 1990, Brito et al. 2002, Møller et al. 2004). It is also distributed from Canada (lat $62^{\circ} 55^{\prime} \mathrm{N}$ ) to Cape Cod in the West Atlantic (Hardy and Stehmann 1990, Møller et al. 2004). The species has also been reported from the
Mid-Atlantic Ridge (lat $37^{\circ} 18^{\prime} \mathrm{N}$ ), off the Azores (Marques and Porteiro 2000).

Hydrolagus affinis can be separated from the other three congeneric species occurring in the NE Atlantic by a number of morphologic characters, including its uniform darker colouration, purplish-brown at all life stages (Hardy and Stehmann 1990, Moura et al. 2005).

Following several deepwater surveys off the Madeira Islands and the nearby Seine Seamount, this species was caught and is here recorded for the first time.

Two longline surveys of the benthic fauna of the Madeira Islands and the Seine Seamount between $750 \mathrm{~m}$ and $2500 \mathrm{~m}$ of depth were carried out (Fig. 1). All the specimens studied were caught during these two cruises on board the Portuguese R/V ARQUIPELAGO: Recprofmad-1 (October 11-November 9, 2004) and Chacmad-1 (September 30-October 21, 2005). On average, bottom longlines were deployed for 4-6 h. Bait used was salted Atlantic chub mackerel (Scomber colias).

Voucher specimens were deposited in the collections of the Museu Municipal do Funchal (História Natural) (MMF) and the Museo de Ciencias Naturales de Tenerife (TFMC). Additional material deposited in MMF from the

\footnotetext{
${ }^{*}$ Correspondence: Dra. Mafalda Freitas, Estação de Biologia Marinha do Funchal, Cais do Carvão, 9000-107 Funchal, Madeira, Portugal, phone: +351 291700360, fax: +351291700339, e-mail: mafalda.freitas@cm-funchal.pt.
} 
Lucky Strike hydrothermal vent field (off the Azores) was also examined. Finally, unpreserved material sampled in the Canary Islands was included in the present study for comparison purposes.

All specimens were measured to the nearest $\mathrm{mm}$ following Didier and Séret (2002).

Hydrolagus affinis (de Brito Capello, 1868) (Fig. 2)

Material examined: $13 \mathrm{H}$. affinis specimens. Archipelago of Madeira and Seine Seamount: MMF35996, $1023 \mathrm{~mm}$ total length (TL), female, Bay of Funchal, Madeira, $32^{\circ} 33^{\prime} \mathrm{N}, 16^{\circ} 50^{\prime} \mathrm{W}, 2500 \mathrm{~m}$, cruise Recprofmad-1, sta. 5, 16 Oct 2004; MMF36085, 1075 mm TL, male, and MMF36089, $1268 \mathrm{~mm} \mathrm{TL}$, female, Seine Seamount, $33^{\circ} 45^{\prime} \mathrm{N} \quad 14^{\circ} 22^{\prime} \mathrm{W}, 2500 \mathrm{~m}$, cruise Recprofmad-1, sta. 34, 4 Nov 2004; MMF36786, 1068 mm TL, male, off Ilhéu de Baixo, SE of Porto Santo, $33^{\circ} 01^{\prime} \mathrm{N}, 16^{\circ} 12^{\prime} \mathrm{W}, 1500 \mathrm{~m}$, cruise Chacmad-1, sta. 10, 6 Oct 2005; MMF8639, 1097 mm TL, female, 16 Jun 1956,

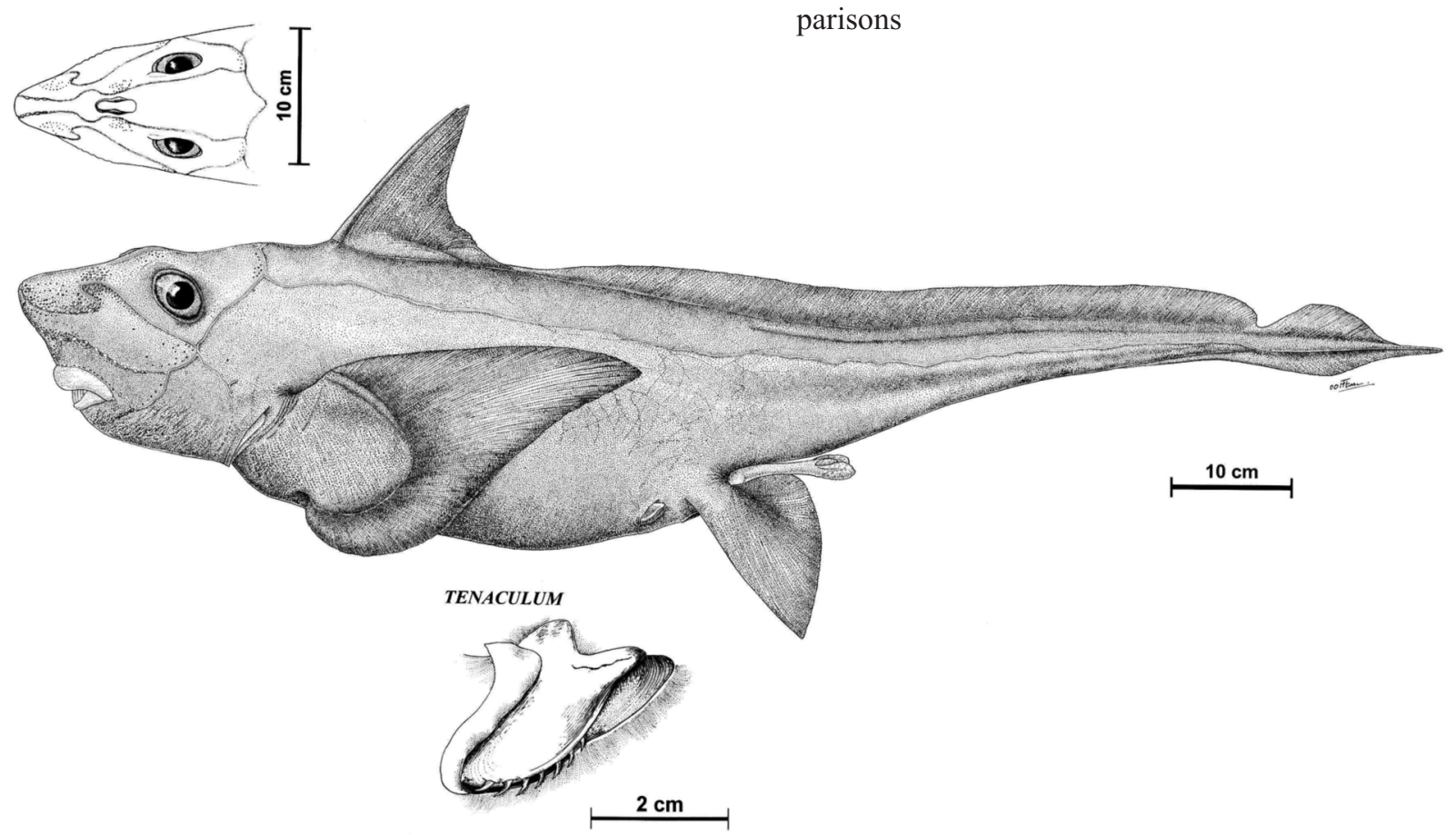

Fig. 2. Hydrolagus affinis from Madeira (MMF25291, 1155 mm TL, 804 mm BDL, Ponta do Sol, 1700 m) (courtesy of H. Encarnação)

Selected body proportions of Hydrolagus affinis from Madeira Islands and Seine Seamount, the Canary Islands and the Azores (Lucky Strike hydrothermal vent) compared with data from literature

\begin{tabular}{lcccc}
\hline Area & $\begin{array}{c}\text { Madeira and Seine } \\
\text { Seamount }\end{array}$ & Canary Islands & $\begin{array}{c}\text { Azores (Lucky Strike } \\
\text { hydrothermal vent) }\end{array}$ & NE Atlantic \\
\hline Reference & PRS & PRS & PRS & H and S \\
No. of specimens & 7 & 5 & 4 & 20 \\
BDL [mm] & $675-913$ & $704-770$ & $645-908$ & $151-885$ \\
HDL in BDL & $25.6-31.0$ & $24.8-29.3$ & $27.0-28.6$ & $19.6-29.4$ \\
HDL in TL & $17.8-20.7$ & $16.8-21.1$ & $16.1-18.7$ & - \\
BDL in TL & $64.9-69.6$ & $63.0-67.7$ & $59.6-66.8$ & - \\
\hline
\end{tabular}

PRS = presently reported study, $\mathrm{H}$ and $\mathrm{S}=$ Hardy and Stehmann, $1990, \mathrm{BDL}=$ body length range, $\mathrm{HDL}$ in $\mathrm{BDL}=\%$ head length in body length, HDL in TL $=\%$ head length in total length, BDL in TL $=\%$ Body length in total length. 
and MMF24350, 913 mm TL, female, off Câmara de Lobos, Madeira, 32 $37^{\prime} \mathrm{N} 16^{\circ} 59^{\prime} \mathrm{W}, 800-1200$ m, 29 Apr 1989; MMF25291, $804 \mathrm{~mm}$ TL, male, off Ponta do Sol, Madeira, $32^{\circ} 34^{\prime} \mathrm{N} 17^{\circ} 07^{\prime} \mathrm{W}, 1700 \mathrm{~m}, 21$ Oct 1992 . Canary Islands: TFMCBM-VP/01426, $1118 \mathrm{~mm} \mathrm{TL}$, female, $1973 \mathrm{~m}$, and TFMCBM-VP/01427, $1100 \mathrm{~mm}$ TL, male, 1953 m, 273' $15^{\circ} 53^{\prime} \mathrm{W}$, off Arguineguín, SW of Gran Canaria, cruise Recprofcan-4, sta. 3, 16 Oct 2004. Azores: MMF33918, $1100 \mathrm{~mm}$ TL, male, $1600 \mathrm{~m}, 2$ Jul 2001, MMF33921, 1360 mm TL, female, 1600 m, 2 Jul 2001. Azores: MMF33923, 1000 mm TL, male, 1700 m, 1 Jul 2001, cruise Ventaco-1; MMF33920, 1160 mm TL, male, 1700 m, 22 Sep. 2001, cruise Ventaco-2, sta. 3; all from Lucky Strike hydrothermal vent field, Mid-Atlantic Ridge off Azores, $37^{\circ} 18^{\prime} \mathrm{N} 32^{\circ} 16^{\prime} \mathrm{W}$.

Additional material: 3 specimens $H$. affinis, (2 males, 1 female), 1113-1223 mm TL, off Arguineguín, SW of Gran Canaria, $27^{\circ} 37^{\prime} \mathrm{N} 15^{\circ} 53^{\prime} \mathrm{W}, 1943-2292 \mathrm{~m}$, cruise Recprofcan-4, sta. 3 and 4.

Remarks: Selected body proportions of the specimens studied are shown in Table 1 and are compared with data from the literature.

All specimens examined fit Hardy and Stehmann's (1990) redescription. The body length (BDL)/head length (HDL) relation is similar when comparing Canary, Madeiran and Azorean individuals. Also this Macaronesian BDL/HDL relationship is similar to that obtained from the northeast Atlantic (Hardy and Stehmann 1990) and Greenland (Møller et al. 2004) material. Some differences observed in specimens from the northeast Atlantic can be explained by the inclusion of very small individuals (sized from $151 \mathrm{~mm}$ BDL) in the Hardy and Stehmann's (1990) material.

Moreover, the TL/BDL relation is similar when comparing Canary, Madeiran and Azorean individuals. Also, this Macaronesian TL/BDL relation is similar to that obtained from Greenland (Møller et al. 2004) material. Some differences observed in specimens from Greenland waters can be explained by the inclusion of very large individuals (more than $913 \mathrm{~mm}$ BDL) in the material studied by Møller et al. (2004).

This species commonly occurs on continental slopes and deep-sea plains (Stehman and Bürkel 1984). The results of this study confirm that $H$. affinis also inhabits oceanic islands and seamounts.

Hydrolagus affinis is recorded for the first time from Madeira Island. These records not only enlarge the previously known area of distribution of this species, but also confirm its depth distribution down to $2500 \mathrm{~m}$ of depth.

In 2009 a new project called MARPROF (PCT MAC 2007-2013, MAC/2/065) started and new research surveys are planned to continue the exploration of the deepsea biodiversity in the waters of the Azores, Madeira and the Canary Islands.

\section{ACKNOWLEDGMENTS}

The authors wish to thank the Ventaco cruises teams (Ventox project), the Pescprof consortium, Helena
Encarnação for providing the drawings and the EU FEDER in the framework of the PIC Interreg III B projects Pescprof 1, 2, and 3 (MAC/4.2/M12, 03/MAC/4.2/M8, and 05/MAC/4.2/M11).

\section{REFERENCES}

Bigelow H.B., Schroeder W.C. 1953. Chimaeroids. Pp. 515-562. In: Tee-Van J., Breder C.M., Parr A.E., Schroeder W.C., Schultz L.P. (eds.) Fishes of the western north Atlantic. Part 2. Sawfishes, Guitarfishes, Skates and Rays, Chimaeroids. Yale University. Sears Foundation for Marine Research, New Heaven, CT.

Brito A., Pascual P.J., Falcón J.M., Sancho A., González G. 2002. Peces de las Islas Canarias. Catálogo comentado e ilustrado. Francisco Lemus, La Laguna.

Capello F.B. 1868. Descrição de dois peixes novos provenientes dos mares de Portugal. [Description of two new fishes from Portugal seas.] Jornal de Sciencias Mathematicas, Physicas e Naturaes 1: 314-317. [In Portuguese.]

Didier D.A., Séret B. 2002. Chimaeroid fishes of New Caledonia with description of a new species of Hydrolagus (Chondrichthyes, Holocephali). Cybium 26 (3): 225-233.

Eschmeyer W.N. (ed.). 2010. Catalog of Fishes electronic version. http://research.calacademy.org/ichthyology/catalog/fishcatmain.asp [Accessed on 26 Aug 2010.]

Hardy G.S., Stehmann M.F.M 1990. A new deep-water ghost shark, Hydrolagus pallidus n. sp. (Holocephali, Chimaeridae), from the eastern North Atlantic, and redescription of Hydrolagus affinis (Brito Capello, 1867). Archiv für Fischereiwissenschaft 40: 229-248.

James K.C., Ebert D.A., Long D.J., Didier D.A. 2009. A new species of chimaera, Hydrolagus melanophasma sp. nov. (Chondrichthyes: Chimaeriformes: Chimaeridae), from the eastern north Pacific. Zootaxa 2009 (2218): 59-68.

Marques A., Porteiro F. 2000. Hydrothermal vent mussel Bathymodiolus sp. (Mollusca: Mytilidae): Diet item of Hydrolagus affinis (Pisces: Chimaeridae). Copeia 3: 806-807.

Moura T., Figueiredo I., Bordalo-Machado P., Almeida C., Gordo L.S. 2005. A new deep-water chimaerid species, Hydrolagus lusitanicus n. sp., from off mainland Portugal with a proposal of a new identification key for the genus Hydrolagu (Holocephali: Chimaeridae). in the north-east Atlantic. Journal of Fish Biology 67 (3): 742-751.

DOI: $10.1111 / \mathrm{j} .0022-1112.2005 .00774 . x$.

Møller P.R., Kullberg T., Jørgensen O.A. 2004. New records of Chimaeroid fishes from Greenland waters (North Atlantic), with description of juvenile Chimaera monstrosa and Hydrolagus affinis (Holocephali, Chimaeridae). Cybium 28: 55-60.

Stehman M., Bürkel D.L. 1984. Chimaeridae. Pp. 212-218. In: Whitehead P.J.P., Bauchot M.L., Hureau J.C., Nielsen J., Tortonese E. (eds.) Fishes of the north-eastern Atlantic and the Mediterranean. UNESCO, Paris.

Received: 2 June 2011

Accepted: 28 September 2011 Published electronically: 30 September 2011 